\title{
The protein balance of the honey bee worker
}

\author{
K Crailsheim \\ Institut für Zoologie an der Karl-Franzens-Universität, Universitätsplatz 2, A-8010 Graz, Austria
}

(Received 6 May 1990; accepted 15 June 1990)

\begin{abstract}
Summary - For honey bee workers, protein requirements and consumption, digestion, intestinal absorption and utilisation all depend on the worker's age and functional status in the system of division of labor within the colony. Workers at the stage of nurses play a pivotal role not only in protein digestion but also in its distribution. They are well equipped for digestion of pollen, are rich in protein and produce large amounts of jelly, which they distribute to almost all members of the colony.
\end{abstract}

protein metabolism / nutrition / digestion / polyethism / Apis mellifera

\section{INTRODUCTION}

The honey bee is one of the few insects whose commercial importance lies in being cultivated, not exterminated. This led to intensive investigations of its nutritional needs. Many papers dealt with the types of food foraged by the colonies, the influence of artificial food or the fate of foodstuffs taken up by bees. Nevertheless, many questions concerning protein metabolism remain unanswered, due to the complexity and plasticity of the social system of the bees.

Temporal polyethism of the worker caste depends primarily on the age of the insect; the division of labor is also influenced by the availability of food inside and outside the hive, on the actual needs of the colony (Rösch, 1925, 1930; Lindauer, 1952; Ribbands, 1952; Free, 1965; Michener, 1969; Seeley, 1982; Winston and Neilson Punnet, 1982; Kolmes, 1985) and on season (Merz et al, 1979). Hormone levels influence the beginning of different age-dependent tasks (Robinson, 1987; Robinson et al, 1989). In the last few years more and more genetically determined controlling mechanisms have been investigated (Calderone and Page, 1988; Frumhoff and Baker, 1988; Robinson and Page, 1988; Kolmes et al, 1989; Robinson et al, 1989; Rothenbuler and Page, 1989).

This review describes the protein metabolism of workers with special attention paid to their age and function.

\section{PROTEINACEOUS NUTRIENTS}

When worker larvae hatch, they are provided with jelly from the brood food glands of the nurses (Hanser and Rembold, 1964; Rembold, 1974) until they reach an age of $3.5 \mathrm{~d}$. Afterwards, they receive a mixture of jelly, honey and pollen; this later food mixture has less protein but more carbohydrates (von Rhein, 1956; Kunert and Crailsheim, 1987). Approximately 1/3 
of the dry weight of the jelly fed at first consists of high molecular weight proteins (Habowsky and Shuel, 1959; Patel et al, 1960). The percentage of protein in the food for the young larvae depends not only on the age of the larvae but is also subject to seasonal fluctuations: during 1 summer a decline from more than $50 \%$ (protein of dry weight) to less than $30 \%$ was demonstrated in 2 colonies investigated in parallel (Kunert and Crailsheim, 1987).

Soon after emergence, young bees start to consume honey and beebread from an area near their brood nest (Lotmar, 1938; Lindauer, 1952; Dietz, 1969; Haydak, 1970; Hagedorn and Moeller, 1967). Beebread is the pollen that has been collected by the foragers and prepared for storage in the combs. It is mixed with secretion from workers (Pain and Maugenet, 1966; Maurizio, 1969; Herbert and Shimanuki, 1978) and contains various microorganisms (Pain and Maugenet, 1966; Gilliam et al, 1989). The nutritive value of pollen stored in this manner is higher than that of laboratory-stored pollen (Beutler et al, 1949; Van Der Vorst and Jacobs, 1980). In addition, the newly emerged workers receive food from older bees in trophallactic interactions; Perepelova (1928) observed that bees of $1-3 d$ of age were fed by others whose age ranged from $7-14 \mathrm{~d}$. Free $(1957,1959)$ found that the young bees also received food from workers of other ages; however, he also confirmed that nurses of 7-14 d were predominant in the group of food providers. From about the third day of life, the number of receiving and giving interactions are similar in number, but generally there is rather more transfer from old to young bees than in the opposite direction (Free, 1957). As the age class from 7-14 d provides the protein for the larvae, it could be assumed from the above findings that newly emerged bees receive not only hon- ey but also protein-rich products of the nurse's brood glands.

These trophallactic transfers also occur when bees are caged (Free, 1957; Korst and Velthuis, 1982; Moritz and Hallmen, 1986). Such laboratory experiments were used to prove the transfer of proteinaceous food between nurses and $1 \mathrm{~d}$-old bees (Crailsheim, 1990a). This transfer was also shown in small free-flying colonies (Crailsheim, 1990b).

Pollen is the main natural source of protein for bees; nectar collected by bees contains rather low concentrations of amino acids (Baker and Baker, 1973). The pollen consumption of the workers increases until they reach the age when they become nurses (Lotmar, 1938; Lindauer, 1952; Pain, 1961), after which pollen consumption tends to decrease.

During the winter when there is no food available outside the hive, bees consume the stored food, ie honey and beebread. Beebread is important for surviving the winter as well as for the start of colony repopulation in the spring (Wille et al, 1987).

One way of obtaining protein is cannibalism. In certain situations, such as lack of proteinaceous food, workers may eat eggs and brood (Haydak, 1935, Myser, 1952, Newton and Michl, 1974). This food can lengthen the lifespan of the cannibal bees themselves (Weiss, 1984), or it can be used for brood rearing or feeding the queen (Weiss, 1984; Webster and Peng, 1987; Webster et al, 1987).

\section{QUALITY OF PROTEIN}

That pollen is necessary for a colony has been known for a long time (Eckert, 1942). Two authors laid down the essential foundations for all subsequent work on protein requirements and metabolism in the early 
fifties. Maurizio (1954) described the importance of pollen for the colonies and Groot (1953) described the nutritional value of various sources of protein for the colonies as well as the requirements of individual bees. He classified the following 10 amino acids as being essential for the growth of the honey bee: arginine, histidine, lysine, tryptophan, phenylalanine, methionine, threonine, leucine, isoleucine and valine; the largest requirements were for leucine, isoleucine and valine.

Thus, the nutritional value of the pollen for bees is primarily defined by its absolute and relative content of essential amino acids. Accordingly, pollen from different plants has a different nutritional value for bees. This could be demonstrated by measuring such diverse parameters as the growth and development of the fat body (Maurizio, 1954), the development of hypopharyngeal glands (Maurizio, 1954; Standifer, 1967), lifespan (Maurizio, 1954; Wahl, 1963; Schmidt et al, 1987) or brood rearing (Wahl, 1963; Herbert et al, 1970). Caged bees show the ability to distinguish between different kinds of pollen. They prefer protein-rich pollen (Schmidt and Johnson, 1984) and react to the presence of phagostimulants in pollen (Schmidt, 1985).

Less important for bees in nature than for artificial feeding of bees is the fact that the age of pollen (Dietz and Haydak, 1965; Hagedorn, 1968) and the way it was collected - ie whether the pollen was collected by humans or by bees (Maurizio, 1954) - influences its value for bees.

\section{INTESTINAL TRANSPORT, DIGESTION AND ABSORPTION}

Pollen is ingested either fresh or from beebread. There is no digestion of protein in the crop, as salivary and hypopharyngeal glands do not produce proteolytic enzymes (Arnold and Delage-Darchen, 1978). Amino acids from nectar do not penetrate the crop wall (Crailsheim, 1988a). Pollen grains are quickly transported through the crop to the proventriculus which regulates the passage of all nutrients into the midgut. In agreement with their intensive pollen consumption, the worker caste has the largest proventriculus as compared to the drones and to the queen (Pabst and Crailsheim, 1990). Transport of liquids is regulated according to requirements (Crailsheim, 1988b, c); solid food, ie pollen, is compressed into bolusses by the proventriculus which are then transported through the stomodeal valve, a flexible pipe (Trappman, 1923) into the midgut (Whitcomb and Wilson, 1929; Bailey, 1952; Schreiner, 1952; Barker and Lehner, 1972; Klungness and Peng, 1984a; Peng and Marston, 1986). There, the pollen bolusses are surrounded by peritrophic membranes. They do not leave the tubule of peritrophic membranes (endoperitrophic space) but pass through the anterior intestine into the rectum (Schreiner, 1952). The time required for passage through the midgut depends on the amount of foodstuffs in this section, on the age of the bee and on the way the bees are kept; the length of time from ingestion until pollen, found in the rectum ranged from a few $h$ up to more than $1 \mathrm{~d}$. The long duration is necessary because pollen is difficult to digest, due to its tough wall (Barker and Lehner, 1972; Klungness and Peng, 1984b; Peng et al, 1986). Some types of pollen leave the midgut without being utilized completely (Peng et al, 1985). For a pollen mixture, offered in a formulated diet, an apparent digestibility of $77 \%$ was shown by Schmidt and Buchmann (1985).

The peritrophic membranes form compartments for digestion (Moritz and Crailsheim, 1987) as also described for other 
insects (Terra et al, 1979; Terra and Ferreira, 1981; Terra, 1988, 1990) and contain immobilized aminopeptidases (Peters and Kalnins, 1985). The chemical composition of the membranes depends on the age of the bees (Pabst et al, 1988).

Upon entering the midgut, pollen is thought to be broken down by osmotic shock (Kroon et al, 1974) and/or by the effects of proteolytic enzymes. In another bee (Melipona quadrifasciata), osmotic shock is less pronounced and only causes an opening of the pores on the pollen grains (Martinho, 1975). Gut proteolytic enzymes are only present to a limited extent in the last pupal stage and in emerging bees, but they increase rapidly in the first hours of imaginal life (Moritz and Crailsheim, 1987). Pavlovsky and Zarin (1922) were the first to investigate extensively the proteolytic enzymes in the gut of the honey bee; they found several types. Giebel et al (1971) described 4 endopeptidases with different properties. Dahlman et al (1978) only found 3 endopeptidases, 1 trypsinelike and 2 chymotrypsine-like. Grogan and Hunt $(1980,1984)$ first proved differences in gut proteolytic activity between house bees (those who did not yet forage) and foragers; Moritz and Crailsheim (1987) showed age-dependence and a close correlation with soluble protein content in the midgut. Trypsine-like and chymoptrypsinelike enzymes showed their maximum activity at $\mathrm{pH} 8.5$ and around $\mathrm{pH} 8$ respectively. The highest levels of proteolytic activity were found in the nurse bees; this activity declined when bees started to forage. Low levels were found in bees in winter; the same population of bees showed a slight increase when bees again began to forage and to perform brood-care tasks in spring. Proteolytic activity in the gut of workers is also influenced by the exigency of the bees' social system. Neither a queen nor open brood was necessary for normal de- velopment of intestinal proteolytic activity when bees lived in colonies, but proteolytic levels were much lower if bees were caged, even in groups and with sufficient proteinaceous food. The composition of the diet also influenced proteolytic levels (Crailsheim and Stolberg, 1989).

Only little proteolytic activity was found in the midgut tissue, somewhat more in the ectoperitrophic space and most in the endoperitrophic space where pollen is transported (Moritz and Crailsheim, 1987; Jimenez and Gilliam, 1989). The latter authors postulate a countercurrent flow in the endo- and ectoperitrophic spaces as described for other insects (Terra and Ferreira, 1981; Terra et al, 1985; Terra, 1988, 1990). Such a flow enables the enzymes to be utilized optimally and explains why only small amounts of liquid pass from midgut into the rectum of bees (Crailsheim, 1988b).

There is less information about the absorption of substances through the midgut wall of the honey bee than for other insects (Turunen, 1985). The transport of sugars was shown to be passive by simple diffusion (Crailsheim, 1988d). Subsequent in vivo experiments demonstrated the concentration dependence of leucine transport as well as inhibition of this transport by the structurally similar amino acid isoleucine, but not by glycine, arginine or glutamic acid (Crailsheim, 1988a). This finding of a rather specific carrier mechanism could be confirmed by in vitro experiments which furthermore proved that the transport of leucine is not energy-dependent (Haszonits and Crailsheim, 1990). In vivo as well as in vitro experiments had previously shown different transport kinetics in bees in summer and in winter; transport being faster in summer. These results are in good agreement with data about protein metabolism. Morphological studies offer an explanation for the lower transport capacity 
for amino acid in winter. Freeze-etch studies showed a lower number of particles in the plasma membrane of midgut epithelial cells in winter bees (Pabst and Crailsheim, 1987); such particles are described in mammals as being carriers or membranebound enzymes.

\section{PROTEIN UTILISATION AND TURNOVER}

Large amounts of protein are required during larval development; 1 larva needs about $50 \mathrm{mg}$ jelly to reach a weight of 35 mg (von Rhein, 1956). During about $3.5 \mathrm{~d}$, the high protein content of a $3 \mathrm{mg}$-larva is reduced from nearly $19 \%$ (of fresh weight), to about $9 \%$ (Kunert and Crailsheim, 1987).

If the nursing bees themselves lack proteinaceous food, they can continue to nurse larvae, but only for about 1 week. All larvae fed after this period were found to be unable to reach maturity and were removed by the bees. Protein-deprived nurse bees had lower nitrogen levels in all 3 body sections, as compared to nurses before the onset of protein deprivation. The largest reduction $(-11 \%)$ was seen in the abdomen. Haydak (1935) concludes from these results that the nurses use their own tissue protein for rearing the larvae. Larvae that were nursed deficiently but reached maturity, developed into dwarfed adults (Jay, 1964).

After emergence, bees require protein for imaginal tissue differentiation. They consume a great deal of pollen and receive proteinaceous food from other workers. Upon emerging, they have a nitrogen content of $1.74 \mathrm{mg}$; this increases to 2.65 $\mathrm{mg}$ in 21-38 d-old bees (Haydak, 1934). A comparison of protein- or nitrogen-contentvalues of emerging workers taken from different authors with different methods is giv- en by Kunert and Crailsheim (1988). The protein content at emergence depends on the availability of food outside the hive during the nursing season; the difference between bees nursed during bad pollen harvesting conditions and between those nursed during good conditions amounts to more than $13 \%$.

At the moment of emergence, bees which were destined to survive the winter had a higher protein content than summer bees (Kunert and Crailsheim, 1988). They are reared during late summer and autumn, a period with less pollen available outside the hive but with considerable amounts of beebread inside. Furthermore, much fewer larvae are reared compared to the period from May to July.

During the hive-bound period, the most remarkable protein increase was found in the heads; nurses had about twice the amount found in newly emerged bees (Haydak, 1934). This is due to the system of work allotment in the honey bee community. Workers at the age of nurses have well-developed hypopharyngeal glands (Krathky, 1931; Moskovljevic-Filipovic, 1952; Groot, 1953; Maurizio, 1954; Beams et al, 1959; Fluri et al, 1982; Mortiz and Crailsheim, 1987; Fergusson and Winston, 1988; Suzuki, 1988; Crailsheim and Stolberg, 1989; Knecht and Kaatz, 1990) which are superbly equipped for synthesis of protein-rich secretions (Brouwers, 1982; Takenaka and Kaatz, 1987; Webster et al, 1987; Webster and Peng, 1987; Knecht and Kaatz, 1990; Crailsheim, 1990a). The secretion products of these glands are then distributed throughout the colony. The development of these glands is stimulated by a signal from the brood (Huang and Otis, 1989; Huang et al, 1989) and suppressed by juvenile hormone (Jaycox et al, 1974; Fluri et al, 1982; Liu, 1989) at least at high dosages (Sasagawa et al, 1989). Workers with the highest rates of protein 
synthesis also exhibit the highest protein levels $(4.3 \%)$ in the haemolymph; this is reduced to $1.7 \%$ in foragers (Sinizki and Lewtschenko, 1971). In winter the protein levels are again higher than in summer; this is due to a lower titer of juvenile hormone (Fluri et al, 1982). In summer, when workers stop producing jelly upon reaching the age of foragers, the shrunken hypopharyngeal glands produce other proteins, mainly enzymes (Simpson et al, 1968; Halberstadt, 1980; Sasagawa et al, 1989). The correct development of hypopharyngeal glands depends on proper nutrition (Soudek, 1927; Free, 1961; Maurizio, 1962; Standifer, 1967; Herbert et al, 1977) and on the existence of a social system (Crailsheim and Stolberg, 1989). When Schmidt and Buchmann (1985) offered such a proper pollen-containing diet to a small colony in a flight cage, they determined an average need of $3.07 \mathrm{mg} \mathrm{N}$ for 1 bee of the colony per $28 \mathrm{~d}$. This corresponds to $19.2 \mathrm{mg}$ protein.

The fat body is the general storage organ in the bee larva and contains large amounts of protein. Its composition changes with age (Krajewska and HryniewieckaSzyfter, 1988). Subsequently, it provides material for the newly developing imaginal tissues in pupae (Schnelle, 1923). After emergence, the protein content of the fat body increases until the worker reaches the nurse stage in summer. Protein content is then lower in foragers and highest in bees that survive the winter (Shehata et al, 1981; Fluri and Bogdanov, 1987; Southwick, 1989). Winter bees have higher protein levels in the haemolymph and more protein in their hypopharyngeal glands than foragers in summer (Fluri et al, 1982). Thus, both compartments function, together with the fat body, as protein storing organs. Many proteins circulating in the haemolymph are produced by the fat body (Lensky and Rakover, 1983).
Injections of radioactively labelled amino acids or feeding of labelled protein enable us to determine the site and rate of protein synthesis as well as catabolism. The high activity of hypopharyngeal glands was demonstrated in vivo with tracer methods (Webster and Peng, 1987; Webster et al, 1987; Knecht and Kaatz, 1990; Crailsheim, 1990a). Ninety min after an injection of ${ }^{14} \mathrm{C}$-phenylalanine, nurses had more than $25 \%$ of the radioactivity in the protein fraction of their caput, less than $10 \%$ in the thorax and more than $25 \%$ in the abdomen. Foragers showed similar results in the thorax and abdomen, but contained somewhat less than $10 \%$ in the caput. More than half of the tracer found in the protein fraction of the head of nurses was in the hypopharyngeal glands after $6 \mathrm{~h}$ (Crailsheim, 1990a).

The half-life of total body protein was shortest in foragers (11-13 d), was about $50 \%$ longer in nurses and was about 4 times longer in bees in winter that were taken from the outside of a wintercluster (Crailsheim, 1986). The reduction of metabolism in winter bees (Omholt and Lonvik, 1986) is a useful adaptation to the lessening of the duties of these bees. Many of them remain almost motionless during long periods on the outside of the cluster and therefore should not need much protein turnover. Nurses in summer that have to do the work of digestion for a large part of the colony need much protein and have a faster turnover. Their enzymatic equipment is adapted to this level of protein metabolism.

Foragers are highly active flyers and cover on average $21.5 \mathrm{~km}$ per $d$ (Neukrich, 1982) which requires the metabolic equivalent of more than $6 \mathrm{mg}$ sugar solely for flight (Heran and Crailsheim, 1988); such an amount of metabolic work is certainly bound to increase protein turnover. Accordingly, they are able to absorb more 
leucine and probably more other amino acids than winter bees (see previous section).

Honey bees are known to use carbohydrates for their energy requirements during flight (Nachtigall et al, 1989). Nevertheless, a considerable fraction of ${ }^{14} \mathrm{C}$ from ${ }^{14} \mathrm{C}$ amino acids was shown to be exhaled as ${ }^{14} \mathrm{CO}_{2}$ (Webster et al, 1987; Crailsheim, $1988 \mathrm{a}, 1990 \mathrm{a}$ ) in bees that were resting or walking, showing that amino acids are ultimately broken down and utilized for energy metabolism. The latter function in other situations than flight requires further investigation.

\section{ACKNOWLEDGMENTS}

I acknowledge the critical reading of the manuscript by $A$ Bucsics and the help with the literature by $B$ Schöffmann. Experiments carried out at the Department for Zoology in Graz were supported by the Fonds zur Förderung der Wissenschaftlichen Forschung, project nos 5674 and 7069 .

Résumé - Le métabolisme des protéines chez l'ouvrière d'abeille. II existe, au sein de la caste de ouvrières, des différences dans le métabolisme des protéines dues à des facteurs tels que l'alimentation, l'âge des abeilles, leur fonction au sein de la colonie.

Les abeilles récemment écloses consomment du pollen et du miel en quantités croissantes et reçoivent également de la nourriture larvaire de la part des congénères de la ruche plus âgées. Leur teneur en protéines s'élève, pendant cette période, puis reste à un niveau élevé jusqu'à la fin de leur vie. La teneur en protéases intestinales et la taille des glandes hypopharyngiennes augmentent continuellement.
A l'âge de $8 \mathrm{j}$, dans une colonie moyenne et dans des conditions normales de miellée, elles occupent la fonction de nourrices, pour laquelle elles consomment d'énormes quantités de pollen. Elles sont alors abondamment pourvues de protéases intestinales et le transport des acides aminés de l'intestin dans l'hémolymphe est réalisé par des mécanismes spécifiques. Ce transport - qui a été étudié pour la leucine - se passe de la même façon chez les nourrices et les butineuses, mais il est plus lent chez les abeilles de la grappe hivernale. Les glandes nourricières des nourrices sont bien développées et produisent une nourriture larvaire riche en protéines, distribuée au couvain et à la reine, mais aussi aux ouvrières de tous âges. Quand les abeilles passent au stade de butineuses, leurs glandes hypopharyngiennes diminuent et changent de fonction.

La circulation des protéines corporelles des nourrices est semblable à celle des butineuses pendant la période de miellée, mais elle est beaucoup plus rapide que chez les abeilles d'hiver.

métabolisme des protéines / nutrition / digestion / polyéthisme / Apis mellifera

\section{Zusammenfassung - Der Proteinstoff- wechsel von Arbeiterinnen der Honig- biene. Innerhalb der Kaste der Arbeiterin- nen bestehen Unterschiede im Eiweißstoffwechsel, die von Faktoren wie Ernährung, individuelles Alter und Funktion innerhalb der Stockgemeinschaft beein- flußt werden. Frisch geschlüpfte Bienen fressen in zunehmendem Maße Pollen und Honig und werden auch von älteren Stock- genossinnen mit Futtersaft gefüttert. Sie erhöhen Ihren Eiweißgehalt während die- ser Zeit, der dann bis zu ihrem Lebens- ende auf hohem Niveau bleibt. Der Gehalt an intestinalen Proteasen und die Größe der Hypopharynxdrüsen nimmt kontinuier- lich zu.}


Im Alter von etwa 8 Tagen haben sie in einem durchschnittlichen Volk bei normalen Trachtverhältnissen die Funktion von Ammen, in der sie sehr große Mengen an Pollen fressen. Sie sind hierzu reichlich mit intestinalen Proteasen ausgestattet, und der Transport von Aminosäuren aus dem Darm in die Hämolymphe wird durch spezielle Trägermechanismen bewerkstelligt. Dieser Transport - untersucht für die Aminosäure Leucin - geschieht bei Ammenbienen und bei Sammlerinnen in ähnlicher Weise, bei Bienen die in der Wintertraube leben jedoch langsamer. Die Futtersaftdrüsen der Ammen sind groß und produzieren eiweißreichen Futtersaft, der an die Brut, die Königin, aber auch an Arbeiterinnen aller Altersstufen verfüttert wird. Beim Übergang zur Ausflugtätigkeit werden die Hypopharynxdrüsen kleiner und ändern ihre Funktion.

Der Umsatz des Körperproteins von Ammenbienen ist während der Trachtzeit dem von Flugbienen ähnlich, er geschieht aber wesentlich rascher als bei Arbeiterinnen, die im Winter leben.

\section{Proteinstoffwechsel / Ernährung / Ver- dauung / Polyethismus / Apis mellifera}

\section{REFERENCES}

Arnold G, Delage-Darchen B (1978) Nouvelles données sur l'équipement enzymatique des glandes salivaires de l'ouvrière d'Apis mellifica (Hymenoptère, Apidae). Ann Sci Nat Zool 20, 401-422

Bailey $L$ (1952) The action of the proventriculus of the worker honeybee. Apis mellifera L. $J$ Exp Biol 29, 310-326

Baker HG, Baker I (1973) Amino-acids in nectar and their evolutionary significance. Nature 241, 543-545

Barker RJ, Lehner Y (1972) A look at honeybee gut functions. Am Bee J 112, 336-338
Beams HW, Tahmisian TN, Anderson E, Devine $R L$ (1959) An electron microscope study on the pharyngeal glands of the honeybee. $J$ U/trastruct Res 3, 155-170

Beutler R, Opfinger E, Wahl O (1949) Pollenernährung und Nosemabefall der Honigbiene. $Z$ Vergl Physiol 32, 383-421

Brouwers EVM (1982) Measurement of hypopharyngeal gland activity in the honeybee. $J$ Apic Res 21, 193-198

Calderone NW, Page RE Jr (1988) Genotypic variability in age polyethism and task specialization in the honey bee, Apis mellifera ( $\mathrm{Hy}$ menoptera: Apidae). Behav Ecol Sociobiol $22,17-25$

Crailsheim K (1986) Dependence of protein metabolism on age and season in the honeybee (Apis mellifica carnica Pollm). J Insect Physiol $32,629-634$

Crailsheim K (1988a) Transport of leucine in the alimentary canal of the honeybee (Apis mellifera $L$ ) and its dependence on season. $J / n$ sect Physio/ 34, 1093-1100

Crailsheim K (1988b) Regulation of food passage in the intestine of the honeybee (Apis mellifera L). J Insect Physio/ 34, 85-90

Crailsheim K (1988c) Intestinal transport of glucose solution during honeybee flight. In: Biona report 6 (Nachtigall W, ed) Gustav Fischer, New York, 119-128

Crailsheim $\mathrm{K}$ (1988d) Intestinal transport of sugars in the honeybee (Apis mellifera L). $J / n$ sect Physio/ 34, 839-845

Crailsheim K, Stolberg $E$ (1989) Influence of diet, age and colony condition upon intestinal proteolytic activity and size of the hypopharyngeal glands in the honeybee (Apis mellifera L). J Insect Physiol 35, 595-602

Crailsheim K (1990a) Protein synthesis in the honeybee (Apis mellifera $\mathrm{L}$ ) and trophallactic distribution of jelly among imagos in laboratory experiments. Zool Jahrb (in press)

Crailsheim K (1990b) Interadult feeding of jelly in honeybee colonies (Apis mellifera L). J Comp Physiol (in press)

Dahimann B, Jany KD, Pfleiderer G (1978) The midgut endopeptidases of the honey bee (Apis mellifica): comparison of the enzymes in different ontogenetic stages. Insect Biochem 8, 203-211 
Dietz A, Haydak MH (1965) Causes of nutrient deficiency in stored pollen for development of newly emerged honey bees. Proc Int Jubilee Beekeeping 20th Congr Bucharest, Apimonida Publ House, Bucharest, 238-241

Dietz A (1969) Initiation of pollen consumption and pollen movement through the alimentary canal of newly emerged honey bees. Ann Entomol Soc Am 62, 43-46

Eckert JE (1942) The pollen required by a colony of honeybees. J Econ Entomol 35, 309311

Fergusson LA, Winston ML (1988) The influence of wax deprivation on temporal polyethism in honey bee (Apis mellifera $L$ ) colonies. Can J Zool 66, 1997-2001

Fluri P, Bogdanov S (1987) Age dependence of fat body protein in summer and winter bees (Apis mellifera) In: Chemistry and Biology of Social Insects (Eder J, Rembold $\mathrm{H}$, eds) J Peperny, München, 170-171

Fluri $P$, Lüscher $M$, Wille $H$, Gerig $L$ (1982) Changes in weight of the pharyngeal gland and haemolymph titres of juvenile hormone, protein and vitellogenin in worker honey bees. $J$ insect Physiol 28, 61-68

Free JB (1957) The transmission of food between worker honeybees. Br J Anim Behav $5,41-47$

Free JB (1959) The transfer of food between the adult members of a honeybee community. Bee World 40, 193-201

Free JB (1961) Hypopharyngeal gland development and division of labour in honey-bee (Apis mellifera $L$ ) colonies. Proc $R$ Entomol Soc Lond 36A, 5-8

Free JB (1965) The allocation of duties among worker honeybees. Symp Zool Soc Lond 14, 39-59

Frumhoff PC, Baker J (1988) A genetic component to division of labour within honey bee colonies. Nature 333, 358-361

Giebel W, Zwilling R, Pfleiderer G (1971) The evolution of endopeptidases - XII. The proteolytic enzymes of the honeybee (Apis mellifica L). Comp Biochem Physio/ 38B, 197-210

Gilliam M, Prest DB, Lorenz BJ (1989) Microbiology of pollen and bee bread: taxonomy and enzymology of molds. Apidologie 20, 53-68

Grogan DE, Haunt JH (1980) Age correlated changes in midgut protease activity of the honeybee, Apis mellifera (Hymenoptera: Apidae). Experientia 36, 1347-1348

Grogan DE, Hunt JH (1984) Chymotrypsin-like activity in the honeybee midgut: patterns in a three-year study. J Apic Res 23, 61-63

Groot de AP (1953) Protein and amino acid requirements of the honeybee (Apis mellifica L). Physiol Comp CEcol 3, 197-285

Habowsky J, Shuel RW (1959) Separation of the protein constituents of the larval diets of the honey bee by continous flow electrophoresis. Can J Zool 37, 957-964

Hagedorn HH, Moeller FE (1967) The rate of pollen consumption by newly emerged honeybees. J Apic Res 6, 159-162

Hagedorn HH (1968) Effect of the age of pollen used in pollen supplements on their nutritive value for the honeybee I. Effect on thoracic weight, development of hypopharyngeal glands, and brood rearing. $J$ Apic Res 7, 8995

Halberstadt K (1980) Elektrophoretische Untersuchungen zur Sekretionstätigkeit der Hypopharynxdrüse der Honigbiene (Apis mellifera L). Insectes Soc 27, 61-77

Hanser G, Rembold H (1964) Analytische und histologische Untersuchungen der Kopf- und Thoraxdrüsen bei der Honigbiene Apis mellifera. $Z$ Naturforsch 19B, 938-943

Haszonits O, Crailsheim K (1990) Uptake of Lleucine into isolated enterocytes of the honeybee (Apis mellifera $L$ ) depending on season. J Insect Physiol (in press)

Haydak MH (1934) Changes in total nitrogen content during the life of the imago of the worker honeybee. J Agric Res 49, 21-28

Haydak MH (1935) Brood rearing by honeybees confined to a pure carbohydrate diet. $J$ Econ Entomol 28, 657-660

Haydak MH (1970) Honey bee nutrition. Annu Rev Entomol 15, 143-156

Heran $H$, Crailsheim K (1988) Energy requirements in bees (Apis mellifera carnica Pollm) in free flight, with and without additional load. Veröffentlichungen der Universität Innsbruck, 167, p 77

Herbert EW, Bickley WE, Shimanuki H (1970) The brood-rearing capability of caged honey bees fed dandelion and mixed pollen diets. $J$ Econ Entomol 63, 215-218 
Herbert EW Jr, Shimanuki H (1978) Chemical composition and nutritive value of the beecollected and bee-stored pollen. Apidologie 9, 33-40

Herbert EW Jr, Shimanuki H, Caron D (1977) Optimum protein levels required by honey bees (Hymenoptera, Apidae) to initiate and maintain brood rearing. Apidologie 8,141 146

Huang ZY, Otis GW (1989) Factors determining hypopharyngeal giand activity of worker honey bees (Apis mellifera L). Insectes Soc 36, 264-276

Huang ZY, Otis GW, Teal PEA (1989) Nature of brood signal activating the protein synthesis of hypopharyngeal gland in honey bees, Apis mellifera (Apidae: Hymenoptera). Apidologie 20, 455-464

Jay SC (1964) Starvation studies of larval honey bees. Can J Zool 42, 455-462

Jaycox ER, Skowronek W, Guynn G (1974) Behavioral changes in worker honey bees (Apis mellifera) induced by injection of a juvenile hormone mimic. Ann Entomol Soc Am 67, 529-534

Jimenez DR, Gilliam M (1989) Age-related changes in midgut ultrastucture and trypsin activity in the honey bee, Apis mellifera. Apidologie 20, 287-303

Klungness LM, Peng YS (1984a) Scanning electron microscope observation of pollen food bolus in the alimentary canal of honeybees (Apis mellifera L). Can J Zool 62, 13161319

Klungness LM, Peng YS (1984b) A histochemical study of pollen digestion in the alimentary canal of honeybees (Apis mellifera $\mathrm{L}$ ). $\mathrm{J}$ Insect Physiol 30, 511-521

Knecht D, Kaatz HH (1990) Patterns of larval food production by hypopharyngeal glands in adult worker honey bees. Apidologie 21 (5), 457-468

Kolmes SA (1985) A quantitative study of the division of labour among worker honey bees. $Z$ Tierpsychol 68, 287-302

Kolmes SA, Winston ML, Fergusson LA (1989) The division of labor among worker honey bees (Hymenoptera: Apidae): The effects of multiple patrilines. J Kansas Entomol Soc $62,80-95$
Kost PJAM, Velthuis HHW (1982) The nature of trophallaxis in honeybees. Insectes Soc 29, 209-221

Krajewska K, Hryniewiecka-Szyfter Z (1988) Histological changes in the fat body of Apis mellifera $\mathrm{L}$ during larval and pupal development. Bull Soc Amis Sci Lett Poznan Ser D Sci Biol 27, 25-36

Kratky E (1931) Morphologie und Physiologie der Drüser in Kopf und Thorax der Honigbiene (Apis mellifica L). $Z$ Wiss Zool 139, 120-200

Kroon GH, Praagh van JP, Velthuis HHW (1974) Osmotic shock as a prerequisite to pollen digestion in the alimentary tract of the worker honeybee. J Apic Res 13, 177-181

Kunert K, Crailsheim K (1987) Sugar and protein in the food for honeybee worker larvae. In: Chemistry and Biology of Social Insects (Eder J, Rembold H, eds) J Peperny, München, 164-165

Kunert K, Crailsheim K (1988) Seasonal changes in carbohydrate, lipid and protein content in emerging worker honeybee and their mortality (Apis mellifera L). Comp Biochem Physiol 75B, 607-615

Lensky Y, Rakover Y (1983) Separate protein body compartments of the worker honeybee (Apis mellifera L). Comp Biochem Physiol 75B, 607-615

Lindauer M (1952) Ein Beitrag zur Frage der Arbeitsteilung im Bienenstaat. $Z$ Vergl Physiol 34, 299-345

Liu TP (1989) Juvenile hormone III induced ultrastructural changes in the hypopharyngeal glands of honeybee Apis mellifera L (Hymenoptera: Apidae) without and with infection by Nosema apis Zander (Microsporidae: Nosematidae). Int $J$ insect Morphol Embryol 18, 73-83

Lotmar R (1938) Untersuchungen über den Eisenstoffwechsel der Insekten, besonders der Honigbienen. Rev Suisse Zool 45, 237-271

Martinho MR (1975) Beiträge zur Untersuchung der Verdaulichkeit der Pollenkörner für Melipona quadrifiasciata, Anthidioides lepeletier (Hymenoptera, Apidae, Meliponinae). 25th Int Apic Congr Grenoble France, Apimondia Publ House, Bucharest, 326 
Maurizio A (1954) Pollenernährung und Lebensvorgänge bei der Hongibiene (Apis mellifica L). Landwirtsch Jahrb Schweiz 62, 115-182

Maurizio A (1959) Factors influencing the lifespan of bees. Ciba Foundation Symp 231243

Maurizio A (1962) Zuckerabbau unter der Einwirkung der invertierenden Fermente in Pharynxdrüsen und Mitteldarm der Honigbiene (Apis mellifica L) 5. Einfluß von Alter und Ernährung der Biene auf die Fermentaktivität der Pharynxdrüse. Ann Abeille 5, 215-232

Merz R, Gerig L, Wille H, Leuthold R (1979) Das Problem der Kurz- und Langlebigkeit bei der Ein- und Auswinterung im Bienenvolk (Apis mellifica L): Eine Verhaltensstudie. Rev Suisse Zool 86, 663-671

Michener CD (1969) Comparative social behavjor of bees. Annu Rev Entomol 14, 299-342

Moritz B, Crailsheim K (1987) Physiology of protein digestion in the midgut of the honeybee (Apis mellifera L). Insect Physiol 33, 923-931

Moritz RFA, Hallmen M (1986) Trophallaxis of worker honeybees (Apis mellifera $L$ ) of different ages. Insectes Soc 33, 26-31

Moskovljevic-Filipovic $V$ (1952) The development of the pharyngeal glands of the honeybee in the normal bee colony. Bull Acad Serbe Sci 4, 257-262

Myser WC (1952) Ingestion of eggs by honey bee workers. Am Bee J 92,67

Nachtigall $W$, Rothe U, Feller $P$, Jungmann $R$ (1989) Flight of the honey bee. III. Flight metabolic power calculated from gaz analysis, thermoregulation and fuel consumption. $J$ Comp Physiol 158B, 729-737

Neukirch A (1982) Dependence of the life span of the honeybee (Apis mellifica) upon flight performance and energy consumption. $J$ Comp Physiol 146B, 35-40

Newton DC, Michl DJ (1974) Cannibalism as an indication of pollen insufficiency in honeybees: ingestion or recapping of manually exposed pupae. J Apic Res 13, 235-241

Omholt SW, Lonvik K (1986) Heat production in the winter cluster of the honeybee, Apis me/lifera. A theoretical study. J Theor Biol 120, 447-456

Pabst MA, Crailsheim K (1987) Freeze-etch study of age-dependent changes in midgut epithelial cell surfaces of the honeybee. Eur J Cell Biol 43, 25

Pabst MA, Crailsheim K (1990) The proventriculus of worker honeybee pupae, adult workers, drones and queens (Apis mellifera $L$ ). Zool Jahrb 94, 271-289

Pabst MA, Crailsheim K, Moritz B (1988) Agedependent histochemical changes in the peritrophic membranes of the honeybee Apis mellifera (Hymenoptera: Apidae). Entomol Gen 14, 1-10

Pain J, Maugenet J (1966) Recherches biochimiques et physiologiques sur le pollen emmagasiné par les abeilles. Ann Abeille 9, 209-236

Patel NG, Haydak M, Gochnauer TA (1960) Electrophoretic components of the proteins in honeybee larval food. Nature 186, 633-634

Pavlovsky EN, Zarin EJ (1922) On the structure of the alimentary canal and its ferments in the bee (Apis mellifera L). $Q J$ Microsc Sci 56, 509-556

Peng YS, Marston JM (1986) Filtering mechanism of the honey bee proventriculus. Physiol Entomol 11, 433-439

Peng YS, Nasr ME, Marston JM (1985) The digestion of dandelion pollen by adult worker honeybees. Physiol Entomol 10, 75-82

Peng YS, Nasr ME, Marston JM (1986) Release of alfalfa, Medicago sativa, pollen cytoplasm in the gut of the honey bee, Apis mellifera (Hymenoptera: Apidae). Ann Entomol Soc Am 79, 804-807

Perepelova LI (1928) The nurse bees. As cited in: Free JB (1965) Opuit Pas 12, 551-557

Peters W, Kalnins M (1985) Aminopeptidases as immobilized enzymes on the peritrophic membranes of insects. Entomol Gen 11, 2532

Rembold H (1974) Die Kastenbildung bei der Honigbiene, Apis mellifica $\mathrm{L}$ aus biochemischer Sicht. In: Sozialpolymorphismus bei insekten (Schmidt $\mathrm{GH}$, ed) Wissenschaftliche Verlagsgesellschaft, Stutgart

von Rhein W (1956) Über die Ernährung der Arbeitermade von Apis mellifica $\mathrm{L}$ insbesondere in der Altersperiode. Insectes Soc 3, 203-212

Ribbands CR (1952) Division of labour in the honeybee community. Proc $R$ Soc $B, 140$, 32-43 
Robinson GE (1987) Regulation of honey bee age polyethism by juvenile hormone. Behav Ecol Sociobiol 20, 329-338

Robinson GE, Page RE Jr, Strambi C, Strambi A (1989) Hormonal and genetic control of behavioral integration in honey bee colonies. Science 246, 109-112

Rösch GA (1925) Untersuchungen über die Arbeitsteilung im Bienenstaat, I. Teil: Die Tätigkeiten im normalen Bienienstaate und ihre Beziehungen zum Alter der Arbeitsbienen. $Z$ Vergl Physiol 2, 571-631

Rösch GA (1930) Untersuchungen über die Arbeitsteilung im Bienenstaat. II. Teil: Die Tätigkeiten der Arbeitsbienen unter experimental veränderten Bedingungen. $Z$ Vergl Physiol 12, 1-71

Rothenbuhler WC, Page RE Jr (1989) Genetic variability for temporal polyethism in colonies consisting of similarly-aged worker honey bees. Apidologie 29, 433-437

Sasagawa H, Sasaki M, Okada I (1989) Hormonal control of the division of labor in adult honeybees (Apis mellifera L). I. Effect of methophrene on corpora allata and hypopharyngeal gland, and its $\alpha$-glucosidase activity. Appl Entomol Zool 24, 66-74

Schmidt JO (1985) Phagostimulants in pollen. $J$ Apic Res 24, 107-114

Schmidt JO, Johnson BE (1984) Pollen feeding preference of Apis mellifera (Hymenoptera: Apidae), a polyectic bee. The Southwest Entomol 9, 41-47

Schmidt JO, Buchmann SL (1985) Pollen digestion and nitrogen utilization by Apis mellifera L (Hymenoptera: Apidae). Comp Biochem Physiol 82A, 499-503

Schmidt JO, Thoenes SC, Levin MD (1987) Survival of honey bees, Apis mellifera (Hymenoptera: Apidae), fed various pollen sources. Ann Entomol Soc Am 80, 176-183

Schnelle H (1923) Über den feineren Bau des Fettkörpers der Honigbiene. Zool Anz 57, 172-179

Schreiner T (1952) Über den Nahrungstransport in Darm der Honigbiene. Z Vergl Physiol 34, 278-298

Seeley TD (1982) Adaptive significance of the age polyethism schedule in honeybee colonies. Behav Ecol Sociobiol 11, 287-293
Shehata SM, Towsend GF, Shuel RW (1981) Seasonal physiological changes in queen and worker honeybees. $J$ Apic Res 20, 69-78

Simpson J, Riedel IBM, Wilding N (1968) Invertase in the hypopharyngeal glands of the honeybee. J Apic Res 7, 29-36

Sinizki NN, Lewtschenko IW (1971) Der Gehalt an Eiweiß und freien Aminosäuren in der Hämolymphe der Arbeitsindividuen der Honigbiene. 23rd Int Beekeeping Congr Moscow, Apimondia Publ House, Bucharest, 361364

Soudek S (1927) The pharyngeal glands of the honeybee (Apis mellifica L). As cited in: Groot de AP (1953) Czech with English summary. Bull Éc Sup Agron 10, 1-63

Southwick EE (1989) Seasonal differences in honey bees. Am Bee J 129, 451-452

Standifer LN (1967) A comparison of the protein quality of pollens for growth-stimulation of the hypopharyngeal glands and longevity of honey bees, Apis mellifera L (Hymenoptera: Apidae). Insectes Soc 14, 415-426

Suzuki K (1988) The development of hypopharyngeal glands in honey bee workers. Bull Fac Educ Shiba Univ 36, 96-101

Takenaka T, Kaatz HH (1987) Protein synthesis by hypopharyngeal glands of worker honey bees. In: Chemistry and Biology of Social Insects (Eder J, Rembold H, eds), J Peperny, München, 166-167

Terra WR, Ferreira C (1981) The physiological role of the peritrophic membrane and trehalase: digestive enzymes in the midgut and excreta of starved lanvae of Rhynchosciara. $J$ Insect Physiol 27, 325-331

Terra WR (1988) Physiology and biochemistry of insect digestion: an evolutionary perspective. Braz J Med Biol Res 21, 675-734

Terra WR (1990) Evolution of digestive systems of insects. Annu Rev Entomol 35, 181-200

Terra WR, Ferreira C, Bastos F (1985) Phylogenetic considerations of insect digestion. Disaccharidases and the spatial organization of digestion in the Tenebrio molitor larvae. Insect Biochem 15, 443-449

Terra WR, Ferreira C, de Bianchi AG (1979) Distribution of digestive enzymes among the endo- and ectoperitrophic spaces and midgut 
cells of Rhychosciara and its physiological significance. J Insect Physiol 25, 487-494

Trappman W (1923) Anatomie und Physiologie des Zwischendarmes von Apis mellifica. Arch Bienenkd 5, 190-203

Turunen S (1985) Absorption. In: Comprehensive Insect Physiology Biochemistry and Pharmacology (Kerkut GA, Gilbert LI, eds) Pergamon Press, Oxford, New York, Toronto, 241-277

van der Vorst E, Jacobs FJ (1980) Comparison of colony- and laboratory-stored pollen for maintaining the life of caged honeybees. $J$ Apic Res 19, 119-121

Wahl O (1963) Vergleichende Untersuchungen über den Nährwert von Pollen, Hefe, Sojamehl und Trockenmilch für die Honigbiene (Apis mellifica). Z Bienenforsch 6, 209-279

Webster TC, Peng YS (1987) Passage of canibalized tissue among honey bee (Hymenoptera: Apidae) colony members. Ann Entomol Soc Am 80, 814-819
Webster TC, Peng YS, Duffey SS (1987) Conservation of nutrients in larval tissue by cannibalizing honey bees. Physiol Entomol 12, 225-231

Weiss K (1984) Regulierung des Proteinhaushaltes im Bienenvolk (Apis mellifica $\mathrm{L}$ ) durch Brutkannibalismus. Apidologie 15, 339-354

Whitcomb W Jr, Wilson HF (1929) Mechanics of digestion of pollen by the adult honey bee and the relation of undigested parts to dysentery of bees. Wis Res Bull 92, 1-27

Wille $H$, Wille $M$, Kilchenmann $V$, Imdorf $A$ (1987) Die Pollenernährung des überwinternden und auswinternden Bienenvolkes. Forschungsanstalt für Milchwirtschaft, Mitteilungen der Sektion Bienen 2, 1-11

Winston ML, Neilson Punnett E (1982) Factors determining temporal division of labor in honeybees. Can J Zool 60, 2947-2952

Winston ML (1987) The biology of the honey bee. Harvard Univ Press, Cambridge MS 